\title{
Efficiency of artificial collectors for quantitative assessment of sea urchin settlement rates
}

\author{
Marc Balsalobre ${ }^{1}$, Owen S. Wangensteen ${ }^{2}$, Creu Palacín ${ }^{2}$, Sabrina Clemente ${ }^{1}$, \\ José Carlos Hernández ${ }^{1}$

\begin{abstract}
${ }^{1}$ Biodiversidad, Ecología Marina y Conservación, Departamento de Biología Animal (Ciencias Marinas), Facultad de Spain. E-mail: marc.balsalobre@gmail.com

${ }^{2}$ Dept. Biología Animal, Institut de Recerca de la Biodiversitat (IRBIO). Universitat de Barcelona, Avd. Diagonal 643, 08028 Barcelona, Spain.
\end{abstract} \\ Biología, Universidad de La Laguna, Avda. Astrofísico Francisco Sánchez s/n, 38206 La Laguna, Tenerife, Canary Islands,
}

\begin{abstract}
Summary: We tested the suitability of three different kinds of artificial collectors designed for quantitative assessment of echinoid settlement rates: (1) nylon nets containing plastic biofilter balls, (2) vertical scrub brushes with vegetal bristles and (3) horizontal triangular mats of coconut fibre. We measured the collecting efficiency by counting the number of post-larvae of two sea urchin species (Paracentrotus lividus and Arbacia lixula) gathered by each collector and deployed in two geographic areas: Tenerife (Canary Islands, eastern Atlantic) and Tossa de Mar (Costa Brava, northwestern Mediterranean). The plastic biofilter ball collector proved to be the most efficient design, collecting more settlers of both sea urchin species under all assayed conditions and showing a higher reproducibility than the other two designs. We therefore suggest using plastic biofilter balls in future studies aimed at quantifying echinoid settlement rates.
\end{abstract}

Keywords: settlement; artificial collectors; sea urchins; post-larvae; Mediterranean; Canary Islands.

Comparación de diferentes tipos de colectores artificiales para cuantificar el asentamiento de erizos de mar

Resumen: En este trabajo comparamos la eficacia de tres tipos diferentes de colectores artificiales diseñados para cuantificar la tasa de asentamiento larvario en equinoideos. Los tres tipos de colectores utilizados en el estudio fueron: (1) mallas de nylon rellenas con biofiltros esféricos de plástico, (2) cepillos verticales con cerdas de fibra vegetal y (3) alfombras horizontales triangulares de fibra de coco. Se determinó la eficacia de recolección mediante el recuento de las post-larvas de dos especies de erizo de mar (Paracentrotus lividus y Arbacia lixula) capturadas por cada colector, en dos áreas geográficas diferentes: Tenerife (Islas Canarias, Atlántico Oriental) y Tossa de Mar (Costa Brava, Mediterráneo Noroccidental). El colector de biobolas de plástico demostró ser el diseño más eficaz de los tres comparados, al capturar un mayor número de post-larvas de ambas especies de erizo en todas las condiciones ensayadas y con una mayor reproducibilidad que los otros dos diseños. Por tanto, recomendamos el uso de los colectores de "biofilters balls" de plástico para el diseño de futuros experimentos que tengan como objetivo la cuantificación de las tasas de asentamiento de equinoideos.

Palabras clave: asentamiento; colectores artificiales; erizos de mar; post-larvas; Mediterráneo; Islas Canarias.

Citation/Como citar este artículo: Balsalobre M., Wangensteen O.S., Palacín C., Clemente S., Hernández J.C. 2016. Efficiency of artificial collectors for quantitative assessment of sea urchin settlement rates. Sci. Mar. 80(2): 207-216. doi: http://dx.doi.org/10.3989/scimar.04252.13A

Editor: J. Garrabou.

Received: April 14, 2015. Accepted: November 25, 2015. Published: April 13, 2016.

Copyright: (c) 2016 CSIC. This is an open-access article distributed under the Creative Commons Attribution-Non Commercial Lisence (by-nc) Spain 3.0.

\section{INTRODUCTION}

Settlement, defined as the transfer of competent planktonic larvae to the benthos, usually driven by chemical cues (Pawlik 1992), is the central process of the three components of the recruitment of new individuals to populations of benthic organisms, the other two being larval supply and survival of newly settled juveniles (Cameron and Schroeter 1980). Settlement is often the limiting process that prevents the establishment of new populations or the growth of existing ones in both invertebrates (Ólafsson et al. 1994, Balch and Scheibling 2001) and fishes (Victor 1986). Therefore, quantitative assessment of settlement is a key step 
in the study of the population dynamics of marine invertebrates.

Settlement processes have probably been most extensively studied in sea urchins among all marine invertebrates, using a wide range of collecting devices (Rowley 1989, Hernández et al. 2006, Hereu et al. 2012). A reliable and standardized methodology could facilitate the obtaining of suitable models for future settlement studies. Sea urchins play a crucial role in shaping benthic communities and controlling ecological processes in infralittoral ecosystems (Sala et al. 1998, Hernández et al. 2008). Through their grazing activity, high densities of sea urchins can transform complex macrophyte communities into low-diversity, barren habitats (Lawrence 1975, Harrold and Pearse 1987, Sangil et al. 2014) and even at low densities they can significantly impact the algal assemblages (Palacín et al. 1998). In echinoderms with long-lived planktotrophic larvae (2-6 weeks), such as most shallow regular echinoids, the settlement process undergoes great temporal and spatial variability (Ebert et al. 1994, Balch and Scheibling 2001). Fluctuations of two orders of magnitude in settlement rate between years have been reported (Hereu et al. 2004). This great variability, driven by diverse biotic and abiotic factors (Hereu et al. 2004, Hernández et al. 2010), makes it difficult to predict the recruiting behaviour of sea urchins. The lack of a reliable standard methodology for assessing and quantifying settlement, in addition to the lack of knowledge about the larval supply and limited information about post-settlement mortality processes such as micropredation (Bonaviri et al. 2012, Clemente et al. 2013) and intraspecific competition (Jennings and Hunt 2010), are some of the reasons why the population dynamics of sea urchins (and other echinoderms) is still not well understood (Uthicke et al. 2009).

On shallow Atlanto-Mediterranean rocky coasts, there are two major species of sea urchin: Paracentrotus lividus and Arbacia lixula (Kempf 1962, Verlaque 1987, Bulleri et al. 1999). P. lividus is most commonly found on horizontal or gentle sloping surfaces with hard substrata, often in crevices, foraging mainly on fleshy algae and suspended particles (Kempf 1962, Régis 1978, Privitera et al. 2008), whereas A. lixula is more abundant on vertical walls and exposed shores, feeding preferably on sessile invertebrates (Wangensteen et al. 2011). Both species have been related to the formation of barren grounds in the western Mediterranean (Micheli et al 2005, Guidetti and Dulčić 2007, Bonaviri et al. 2011). On the other hand, in the Canarian Archipelago, $P$. lividus and $A$. lixula compete for space within the first few metres of the subtidal zone (down to $5 \mathrm{~m}$ ), since the long-spined sea urchin Diadema africanum (absent in the Mediterranean) outcompetes them in deeper waters (Tuya et al. 2007, Hernández et al. 2008). Though A. lixula is better adapted to water motion and turbulence, $P$. lividus is capable of competing in shallower and more suitable habitats by drilling holes in rocky reefs, where it is protected from the wave action (Tuya et al. 2007).

In contrast to those of $A$. lixula, the gonads of $P$. lividus are a delicacy for humans in most of its distribu- tion area (Irusta et al. 2008). Its economic importance has thus resulted in numerous studies assessing its reproductive cycle (Fenaux 1968, Byrne 1990, SánchezEspaña et al. 2004). Hence, unlike those of A. lixula, the reproductive timing and settlement behaviour of $P$. lividus are well known throughout its distribution range.

Since the 1960s many kinds of artificial collectors have been used to study settlement and recruitment rates of marine invertebrates, and particularly of echinoderms. Oyster shells (Loosanoff 1964), plastic light diffusers (Bak 1985), rigid plastic (Tegner 1989), plastic matrixes with articulated coralline algae in PVC pipes (Harrold et al. 1991, Miller and Emlet 1997, Balch et al. 1998), artificial grass (Lamare and Barker 2001), plastic fish-tank biofilter balls (Keesing et al. 1993, Hernández et al. 2006, Clemente et al. 2009) and scrub brushes with different types of bristles (Ebert et al. 1994, Lamare and Barker 2001, Hereu et al. 2004) are examples of diverse artificial collectors that have been used for different purposes and with varying success. Unfortunately, the numerical results obtained using different kinds of collectors are not readily comparable, and few studies in the literature have compared the performance in the field of different types of collectors (e.g. Hereu et al. 2004, García-Sanz et al. 2012).

Within this study we aimed to assess the efficiency of the three kinds of artificial settlement collectors most commonly used in the past decades: plastic biofilter balls, scrub brushes and coconut fibre mat (analogous to artificial grass and Astroturf). Their suitability for gathering settlers of echinoderms, particularly postlarvae of two species of sea urchins (Arbacia lixula and Paracentrotus lividus), was tested in the shallow coastal waters of two regions, the Canary Islands (eastern Atlantic Ocean) and the northwestern Mediterranean Sea, during two sampling periods. The two sampling periods of 14 and 28 days were tested in order to assess the formation of the biofilm needed for artificial plastic collectors to be suitable for post-larvae settlement.

\section{MATERIALS AND METHODS}

\section{Study sites}

The study was carried out at two localities: Abades $\left(28^{\circ} 08^{\prime} 26^{\prime \prime} \mathrm{N}, 16^{\circ} 26^{\prime} 04^{\prime \prime} \mathrm{W}\right)$, situated in a sheltered bay in SW Tenerife (Canary Islands, Spain), and Tossa de Mar $\left(41^{\circ} 43^{\prime} 02^{\prime \prime} \mathrm{N}, 2^{\circ} 56^{\prime} 04^{\prime \prime} \mathrm{E}\right)$, situated in a similar sheltered bay of the Costa Brava (Girona, Spain) (Fig. 1). Artificial settlement collectors were deployed in February and June 2012, coinciding with the expected timing for the main annual settlement event of Paracentrotus lividus in Abades (Girard et al. 2006, GarcíaSanz 2014) and Tossa de Mar (Lozano et al. 1995, López et al. 1998), respectively.

At the Abades site, the habitat is characterized by barren bottoms consisting of boulders dominated by encrusting coralline algae and scattered patches of filamentous algae. At shallow depths, down to $5 \mathrm{~m}$, erect algae such as Lobophora variegata, Padina pavonica and Dictyota dichotoma can also be found in low den- 


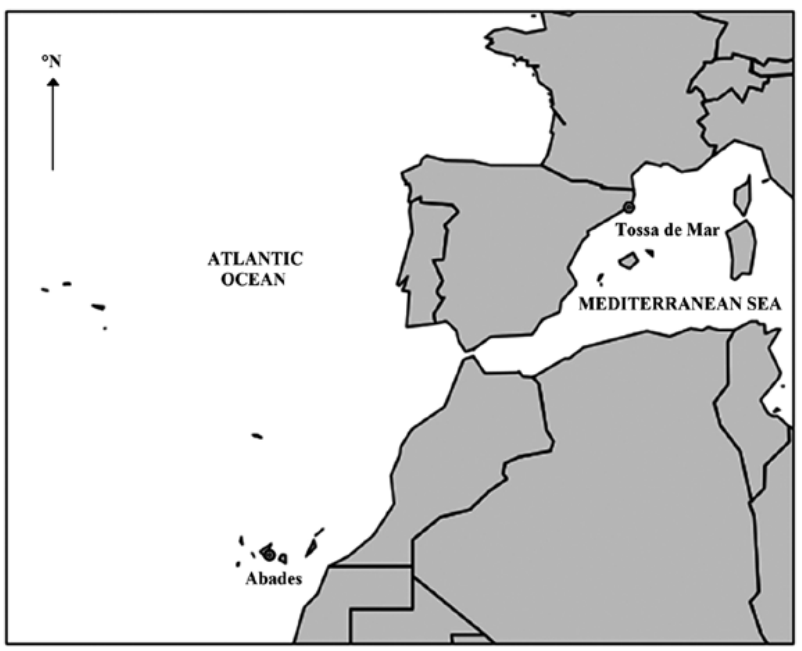

Fig. 1. - Map showing the sampled locations: Abades (Tenerife, Canary Islands) and Tossa de Mar (Costa Brava, northwestern Mediterranean)

sities (Hernández et al. 2008). These gently sloping rocky bottoms host high densities of the sea urchin Diadema africanum (9-12 individuals $\mathrm{m}^{-2}$ ) and lower densities of Paracentrotus lividus and Arbacia lixula (Hernández et al. 2010).
Tossa de Mar seabed is characterized by gradually sloping rocks with some crevices extending from the surface down to $12 \mathrm{~m}$ depth. A rich cover of photophilous algae, such as Dictyota dichotoma, Stypocaulon scoparium, Padina pavonica and Corallina elongata (Wangensteen et al. 2011), and the absence of barren zones allow A. lixula and $P$. lividus to dwell on these bottoms in moderate densities, reaching up to 1.1 and 3.3 individuals $\mathrm{m}^{-2}$, respectively (Wangensteen et al. 2013b).

\section{Artificial settlement collectors}

Three types of artificial settlement collectors successfully and extensively used in past works were tested for their efficiency in this study (Fig. 2): (1) plastic biofilter balls (Hernández et al. 2006, modified from Keesing et al. 1993), (2) scrub brushes with vegetal bristles (Ebert et al. 1994, Tomas et al. 2004) and (3) horizontal triangular mats of coconut fibre.

Following the methodology used by Hernández et al. (2006), one hundred spherical plastic balls (diameter $=3.9 \mathrm{~cm}$ ) originally designed to be used as fishtank filters (biofilters), were packed in a $50 \times 50 \mathrm{~cm}$ thin nylon net and deployed above the seafloor (Fig. 2C). The high surface area provided by the rugosity

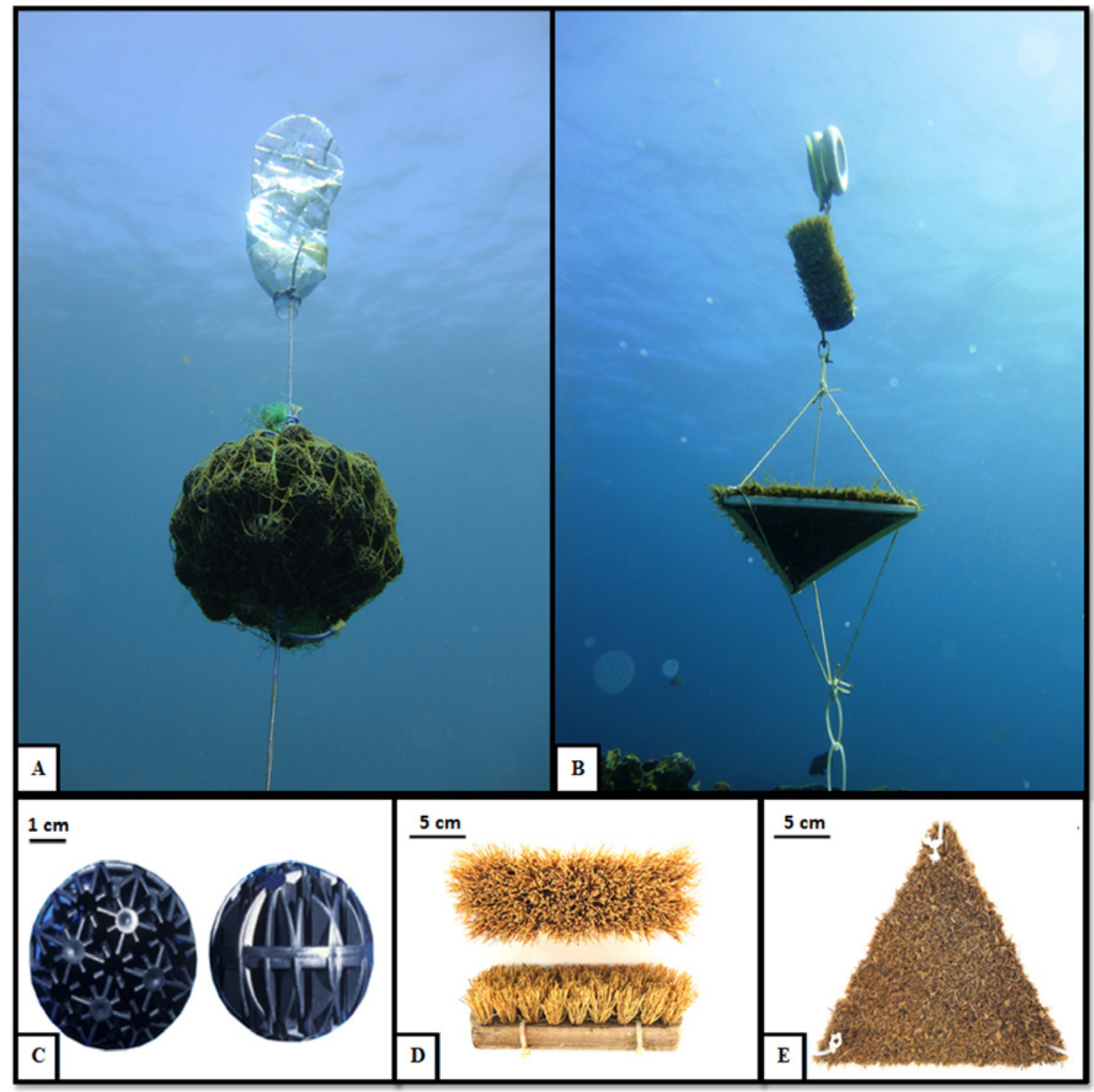

Fig. 2. - The three types of collector tested in this work. General image of (A) the plastic biofilter ball collector and (B) the vertical brush and triangular mat collectors deployed underwater. Detailed image of (C) a single biofilter ball, (D) vertical brush of vegetal bristles and (E) horizontal triangular mat of coconut fibre. 
of the biofilters $\left(0.04 \mathrm{~m}^{2} / \mathrm{ball}\right.$, for a total area of $\left.4 \mathrm{~m}^{2}\right)$, the protection against predators and the darkness in the interior of the collector may favour the settlement and metamorphosis of sea urchin larvae (Hunte and Younglao 1988).

The second design, the brush collector, is a version of the sampler used by Ebert et al. (1994) and has been used as the most effective collector in other studies (Hereu et al. 2004). It consisted of a single commercial scrub brush with a $17 \times 5-\mathrm{cm}$ wooden base and $2.5-\mathrm{cm}$ vegetal fibre bristles, creating an approximate total surface area of $0.3 \mathrm{~m}^{2}$ (Fig. 2D). Individual brushes were set vertically in the water column attached by nylon cable ties to the rope lines.

The third design was made with an equilateral triangular base $(26 \mathrm{~cm}$ side) of a flexible PVC mat with densely packed $1.5-\mathrm{cm}$-long coconut fibres, giving a total surface area of $3.24 \mathrm{~m}^{2}$ (Fig. 2E). This sampler was kept in horizontal position by three nylon cable ties attaching the three vertices of the sampler to the main anchor line. The substrate used in this design resembles Astroturf, which has been extensively used in the past (Lamare and Barker 2001, Jennings and Hunt 2010).

The total surface area of both the scrub brush and mat collectors was estimated by calculating the density of bristles in each device and estimating their average surface area under the stereoscope. The surface area of the individual bristles was calculated by considering them as cylindrical structures and measuring their approximate length and diameter. The average surface area per bristle was obtained after measuring 50 bristles of each collector.

In order to facilitate deployment and recovery operations, brush and mat collectors were attached to the same anchor rope and spaced sufficiently $(40 \mathrm{~cm})$ to ensure minimum interference between them, whereas the biofilter ball collectors were each set on a different line. In all cases, each rope line was anchored to the sea bottom and a subsurface float was set at the top, in order to keep the positive buoyancy of the arrangement within one metre above the seafloor.

\section{Experimental design}

Three replicate sites were randomly designated and spaced approximately 10-15 m apart in the rocky subtidal zone (between $5-10 \mathrm{~m}$ depth) at both study sites. Since two different deployment times (14 and 28 days) were used, two sets of samplers (each formed by a plastic biofilter, a scrub brush and a mat settlement collector), approximately $2 \mathrm{~m}$ apart, were deployed at each replicate site. One set of samplers was collected from each replicate site after 14 days and the other after 28 days.

The three samplers per experimental condition were collected by SCUBA divers, carefully detached from the anchor rope, put into sealed plastic bags, and then brought to the surface and kept in a container for transport. In the laboratory, the settlers were removed from the artificial collectors by rinsing the brushes, mats and individual biofilter balls with a high-pressure freshwater pump. The collected water was filtered through a $200-\mu \mathrm{m}$ steel sieve and the sediment obtained from the filtering process was preserved and stored for later identification in $70 \%$ ethanol $100-\mathrm{ml}$ plastic vials. The collected post-larvae and early juveniles of $P$. lividus and A. lixula were identified and counted under a stereomicroscope.

\section{Statistical analyses}

Densities of newly settled $P$. lividus and A. lixula post-larvae were separately tested for differences between artificial collectors, sampling time and locality by means of two- or three-way permutational multivariate analysis of variance (PERMANOVA) (Anderson 2005). Due to the different total numbers of settlers found between the two sea urchin species, we used a Bray-Curtis similarity matrix calculated on square-root-transformed abundance data, in order for the analyses of the two species to be comparable. We used statistical designs with 10000 permutations in which the factors 'Collector' (3 levels), 'Time' (2 levels) and 'Locality' (2 levels) were treated as fixed factors. When significant differences were detected, post hoc pairwise comparisons of means were performed (Anderson 2004). In cases in which the number of permutations was not high enough to get a reliable test in the pairwise analyses, Monte Carlo asymptotic p-value was used to test for significant differences (Anderson 2005). Permutational analyses were calculated with PRIMER6 and PERMANOVA+ software (Clarke and Gorley 2006).

In order to assess the reproducibility of the replicate results obtained for each type of collector, coefficients of variation $(\mathrm{CV}=$ standard deviation $/$ mean \%) were calculated for every experimental condition (Zar 1984).

\section{RESULTS}

\section{Settlement of Paracentrotus lividus}

Early settlers of Paracentrotus lividus were found in all the artificial collectors deployed at the two study sites, ranging between 4 and 51 individuals at Abades and between 5 and 67 at Tossa de Mar. The comparison between the three types of collector showed parallel

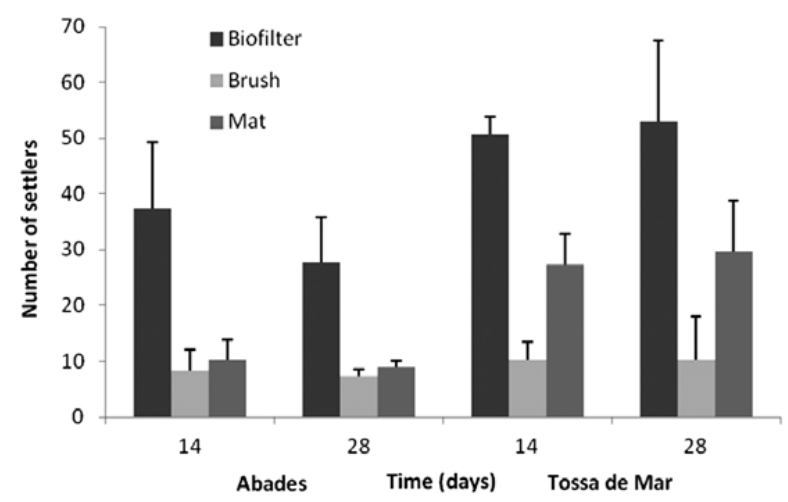

Fig. 3. - Number of Paracentrotus lividus settlers found in the artificial collectors deployed at Abades and Tossa de Mar in February and June 2012, respectively. Error bars show standard deviations. 
Table 1. - Results of the three-way permutational analysis of variance (PERMANOVA) performed to identify significant differences in the number of $P$. lividus settlers between the factors 'Collector', 'Time' and 'Locality' (Abades and Tossa de Mar). Significant results are shown

\begin{tabular}{|c|c|c|c|c|c|}
\hline Source & df & SS & MS & Pseudo-F & $\mathrm{P}($ perm $)$ \\
\hline Collector & 2 & 7996.6 & 3998.3 & 55.075 & $0.0001 * *$ \\
\hline Time & 1 & 35.498 & 35.498 & 0.48897 & 0.5605 \\
\hline Locality & 1 & 1748 & 1748 & 24.078 & $0.0001 * *$ \\
\hline Collector $\times$ Time & 2 & 21.754 & 10.877 & 0.14982 & 0.9502 \\
\hline Collector $\times$ Locality & 2 & 832.84 & 416.42 & 5.736 & $0.005 * *$ \\
\hline Time $\times$ Locality & 1 & 40.324 & 40.324 & 0.55544 & 0.5312 \\
\hline Collector $\times$ Time $\times$ Locality & 2 & 27.938 & 13.969 & 0.19242 & 0.9245 \\
\hline Residual & 24 & 1742.4 & 72.598 & & \\
\hline Total & 35 & 12445 & & & \\
\hline
\end{tabular}

Table 2. - Pairwise comparisons for the significant interaction of factors 'Collector $\times$ Locality' obtained in the permutational analysis of variance (PERMANOVA) assessing differences in number of $P$. lividus settlers. Differences in settler abundances at Abades (in February 2012) and at Tossa de Mar (in June 2012) among the three types of artificial collectors tested are given. Significant results are shown in bold $(* * \mathrm{p}<0.01)$.

\begin{tabular}{llcc}
\hline Locality & Collectors & $\mathrm{T}$ & $\mathrm{P}(\mathrm{MC})$ \\
\hline Abades & Biofilter, Mat & 73.04 & $\mathbf{0 . 0 0 0 3} * *$ \\
& Biofilter, Brush & 66.44 & $\mathbf{0 . 0 0 0 3} * *$ \\
& Mat, Brush & 11.86 & 0.2698 \\
Tossa de Mar & Biofilter, Mat & 44.59 & $\mathbf{0 . 0 0 2 1} * *$ \\
& Biofilter, Brush & 6.78 & $\mathbf{0 . 0 0 0 1} * *$ \\
& Mat, Brush & 4.34 & $\mathbf{0 . 0 0 1 2} * *$ \\
\hline
\end{tabular}

patterns in samplers deployed in the Atlantic Ocean and the Mediterranean Sea (Fig. 3). In all four treatments, biofilter collectors recorded larger numbers of post-larvae/early juveniles of $P$. lividus than brush and mat collectors. Brush and mat collectors gathered similar number of $P$. lividus settlers at Abades, whereas mat collectors gathered more individuals than brushes at Tossa de Mar (Fig. 3).

The three-way PERMANOVA, using locality as well as collector and sampling time as factors for testing settlement rates in the sea urchin P. lividus, showed a significant interaction of the factors 'Collector' $x$ 'Locality' (Table 1). This result indicates contrasting $P$. lividus settlement rates depending on the type of artificial collector used at each sampling site. Pairwise comparisons showed that while at Tossa de Mar all three settlement samplers were significantly different from each other, with biofilters collecting higher numbers of settlers than mat and brush collectors, at Abades only the biofilter collector significantly differed in settlement densities from the other two collectors, but no differences were found between brush and mat collectors (Table 2, Fig. 3). No significant effect of sampling time was found for P. lividus, indicating that the number of collected settlers did not differ between the samplers that were deployed for 14 days and the ones that were deployed for 28 days. This pattern was similar at both sites.

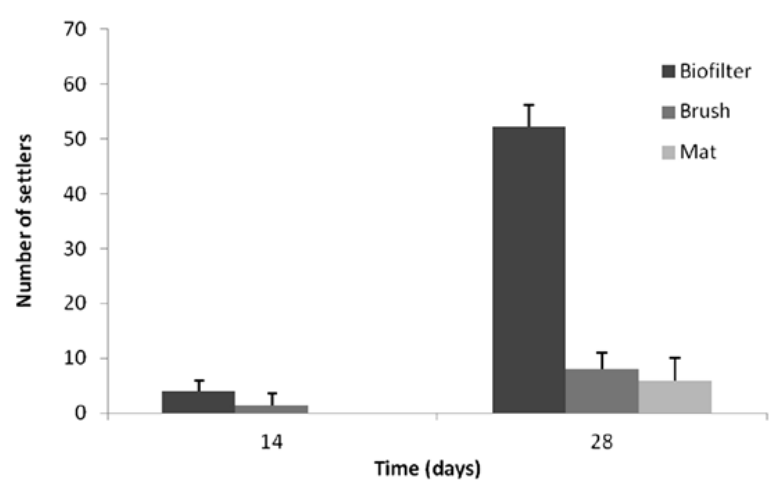

Fig. 4. - Number of Arbacia lixula settlers found in the artificial collectors deployed in Abades in February 2012. Error bars show standard deviation.

\section{Settlement of Arbacia lixula}

No post-larvae or early juveniles of Arbacia lixula were found in any of the collectors set up during the spring of 2012 at the Mediterranean site of Tossa de Mar. In contrast, a variable number of $A$. lixula settlers were found in all three types of collectors deployed at the Abades site in the Canary Islands (Fig. 4). The twoway PERMANOVA using collector type and sampling time as factors showed that the interaction of the two factors had significant effects on settlement rates (Table 3 ), meaning that numbers of A. lixula settlers varied between the type of collectors depending on the sampling time considered. Further pairwise analyses showed significant differences in the number of A. lixula settlers between the biofilter balls and the mat and brush collectors within the 28-day sampling period. However, at the end of the first 14 days of sampling no clear pattern among collectors could be determined, probably due to the small number of settlers collected (Table 4). No significant differences were found between mat and brush collectors in any of the sampling periods (Table 4). In general, similarly to the results for P. lividus, biofilters gathered larger number of settlers than brush and mat

Table 3. - Results of the two-way permutational analysis of variance (PERMANOVA) performed to identify significant differences in the number of A. lixula settlers between the factors 'Collector' and 'Time' at the Canary Islands site (Abades). Significant results are shown in bold $(* * \mathrm{p}<0.01)$.

\begin{tabular}{lcccc}
\hline Source & df & SS & MS & Pseudo-F \\
\hline Collector & 2 & 4371.5 & 2185.7 & 11.387 \\
Time & 1 & 7471.7 & 7471.7 & 38.927 \\
Collector $\times$ Time & 2 & 2490.9 & 1245.5 & 64.887 \\
Residual & 12 & 2303.3 & 191.94 & $\mathbf{0 . 0 0 1 6} * *$ \\
Total & 17 & 16637 & & $\mathbf{0 . 0 0 3 3} * *$ \\
\hline
\end{tabular}


Table 4. - Pairwise comparisons for the significant interaction of the factors 'Collector $\times$ Time' obtained in the permutational analysis of variance (PERMANOVA) assessing differences in number of $A$. lixula settlers collected at Abades in February 2012. Differences in settler abundances between the three types of artificial collectors tested at the different sampling times are given. Significant results are shown in bold $(* * \mathrm{p}<0.01)$.

\begin{tabular}{lccc}
\hline Time & Collectors & $\mathrm{T}$ & $\mathrm{P}(\mathrm{MC})$ \\
\hline 14 days & Biofilter, Brush & 1.83 & 0.1339 \\
& Biofilter, Mat & 9.43 & $\mathbf{0 . 0 0 0 3} * *$ \\
& Mat, Brush & 1.00 & 0.3711 \\
28 days & Biofilter, Brush & 8.67 & $\mathbf{0 . 0 0 0 8} * *$ \\
& Biofilter, Mat & 5.36 & $\mathbf{0 . 0 0 2 8} * *$ \\
& Mat, Brush & 0.79 & 0.4801 \\
\hline
\end{tabular}

collectors, with average values around six times higher after 28 days of sampling (Fig. 4). Although brush collectors experienced just a slight increase in number of settlers between the two sampling periods, differences between biofilter ball collectors were more evident, as they showed densities up to 13 times higher at the end of the 28-day sampling period (Fig. 4). Data from mat collectors showed that no A. lixula post-larvae were found during the first 14 days and a mean of only 6 settlers $\times$ collector $^{-1}$ had settled after four weeks of uninterrupted sampling (Fig. 4). Therefore, settlement densities obtained after the sampling period of 28 days were considerably higher than those obtained during the first 14 days (Fig. 4), probably indicating that most A. lixula post-larvae settled during the last two weeks of the sampling period.

\section{Individuals collected per unit area}

When collected individuals per unit area instead of absolute numbers were considered, figures for brush collectors rose because of their smaller surface area. For P. lividus, brushes significantly collected more individuals per unit area than biofilter balls or mats at both sites (Supplementary material, Fig. S1, Table S1 and Table S2). Whereas for A. lixula the performance of brushes and biofilter balls per unit area did not differ significantly (Fig. S2 and Table S4). The interaction of collector type and sampling time was nonsignificant in this case (Table S3).

\section{Reproducibility of different collectors}

The coefficients of variation for the replicate results obtained in each experimental condition are shown in Table 5. It is noteworthy that the coefficients of variation obtained by the biofilter collectors were the smallest of the three types of collectors in most tested

Table 5. - Coefficients of variation for the number of P. lividus and A. lixula settlers collected by each type of artificial collector at each site (Abades and Tossa de Mar).

\begin{tabular}{lcccc}
\hline \multirow{2}{*}{ Collectors } & \multicolumn{2}{c}{ Abades } & \multicolumn{2}{c}{ Tossa de Mar } \\
& 14 days & 28 days & 14 days & 28 days \\
\hline$P$. lividus in biofilters & $31.7 \%$ & $29.4 \%$ & $6.3 \%$ & $27.4 \%$ \\
$P$. lividus in mats & $45.4 \%$ & $15.8 \%$ & $20.1 \%$ & $30.6 \%$ \\
$P$. lividus in brushes & $34.0 \%$ & $11.1 \%$ & $29.6 \%$ & $73.3 \%$ \\
A. lixula in biofilters & $50 \%$ & $7.2 \%$ & & \\
A. lixula in mats & $173 \%$ & $37.5 \%$ & & \\
A. lixula in brushes & - & $66.7 \%$ & & \\
\hline
\end{tabular}

conditions (with the notable exception of P. lividus at Abades after 28 days), indicating their higher general reproducibility in most cases.

Besides sea urchin settlers, the three types of artificial collectors tested proved to be useful for sampling a wide variety of marine benthic invertebrate groups. Though we did not quantify them in this study, post-larvae or early settlers of different species of Arthropoda (Acarina, Amphipoda, Decapoda, Isopoda, Ostracoda, Pycnogonida), Bryozoa, Mollusca (Bivalvia, Gastropoda), Chaetognatha, Echinodermata and Polychaeta were identified in most collected samples, proving that these collectors may be suitable for quantitative assessment of settlement rates of these taxa.

\section{DISCUSSION}

Our study, aimed at testing the efficiency of artificial settlement collectors, has proven that, of the three types of artificial substrates tested, collectors consisting of fish-tank biofilters are clearly the most effective for quantitative assessment of echinoid settlement rates, despite some differences between habitats and sampling times. For the two sea urchin species selected in this study, Paracentrotus lividus and Arbacia lixula, the biofilter ball collectors gathered larger number of settlers than the mat and brush collectors together (which collected similar number of settlers), and had the highest reproducibility of all three types of collectors in almost all tested conditions. In the case of $A$. lixula, this pattern could only be seen in Atlantic waters due to the absence of settlers in the collectors deployed on the Mediterranean coastline. However, for P. lividus the pattern was consistent in the two sampled habitats of the study sites: the barren grounds in Tenerife Island (Canary Islands) and the photophilous algae meadows of the northwestern Mediterranean.

As reported by Balch and Scheibling (2000), fouling aggregated during the period of deployment upgrades the suitability of the artificial collector by improving the quality of the sampler surface or even the capacity to passively retain new settlers. The amount of biofilm within the surface of the filter balls was noticeably more abundant than that between the bristles of the brush and mat collectors, suggesting that the biofilters may present a more appealing substrate for competent sea urchin larvae. On the other hand, in our experiments, the collectors deployed at the study sites for 14 days were able to collect similar numbers of settlers of P. lividus to those deployed for 28 days. Considering that the fouling was conspicuously more abundant at the end of the 28-day sampling period than at the end of the first 14 days, we would not suggest that there is a direct relation between the volume of fouling aggregated on the collector surface and the number of $P$. lividus post-larvae settled. Although the aggregation of microscopic living organisms and sediment on the surface of the newly deployed collectors may initially enhance their capacity to gather settlers, its accumulation during longer sampling periods remains unclear.

Additionally, the high structural complexity of the biofilters in comparison with brush and mat samplers 
provides sea urchin settlers with a great sheltered area, facilitating protection against predators and therefore decreasing post-settlement mortality rates. The fact that all our collectors were suspended in the water column and isolated from the sea bottom may play a role in excluding epibenthic predators such as decapods (Bonaviri et al. 2012, Clemente et al. 2013), as well as in minimizing the effect of the migration of early juveniles. This is a clear advantage of our experimental design in comparison with previous studies, which have used settlement collectors attached directly to the substrata (Lambert and Harris 2000), although we cannot rule out the possibility that fish predation at this level above the seafloor might play a significant role in the case of mat and brush collectors.

Paracentrotus lividus settlement shows conspicuous seasonality and great inter-annual regularity, displaying synchronicity with planktonic algal blooms in the water column during late and early spring in the western Mediterranean and eastern Atlantic, respectively (López et al. 1998, Tomas et al. 2004, Girard et al. 2006). Following this seasonality, we recorded high numbers of $P$. lividus settlers during the months corresponding to the main annual settlement event at each of the two study sites. The fact that similar numbers of settlers were recorded in the collectors at both sites, regardless of sampling time (14 or 28 days), may have two alternative explanations. Either the settlement event mainly occurred during the first two weeks of deployment of the collectors and the number of post-larvae added during the last two weeks was negligible; or alternatively, the collectors eventually reached a saturation point and were unable to gather new settlers afterwards. Further specific experiments are needed to clarify these issues. Although post-settlement processes may modify the number of surviving settlers and thus determine the success of recruitment, in some echinoid species, such as Strongylocentrotus droebachiensis (Balch and Scheibling 2000), Diadema africanum (Hernández et al. 2010) and Paracentrotus lividus (Hereu et al. 2004, Bonaviri et al. 2012), the settlement process by itself can be a reliable predictor of the recruitment event. In the Mediterranean, six months after a settlement episode, the mortality of recruits has been estimated at about 75\% (Sala and Zabala 1996), and higher than $99 \%$ after the first year (López et al. 1998).

Arbacia lixula is the most widely distributed species of the five extant species in the genus Arbacia (Wangensteen et al. 2012) and it is currently abundant on the shallow rocky bottoms of the Mediterranean Sea (Palacín et al. 1998, Hereu et al. 2012) and subtropical eastern Atlantic (Hernández et al. 2013). Despite its ecological importance (Bulleri et al. 1999, Guidetti et al. 2003, Privitera et al. 2011), settlement and recruitment stages of the black sea urchin have only been studied in the Canary Islands (Hernández et al. 2005, García-Sanz et al. 2014), probably because the occurrence of its settlers in the northwestern Mediterranean basin is inconspicuous and may be easily overlooked (Wangensteen 2013a). Unfortunately, our artificial collectors deployed in Mediterranean waters could not collect any A. lixula post-larvae during the study period (June 2012), so their efficiency could be only tested at Tenerife Island. In contrast to $P$. lividus, for which no significant differences in the abundance of settlers were found regarding small-scale time variations, we collected a considerably higher number of $A$. lixula settlers in the collectors that were deployed for 28 days underwater than in those that were deployed for only 14 days. This implies that most A. lixula post-larvae settled on the collectors during the last two weeks of the sampling period (February 2012). These findings suggest that $P$. lividus and $A$. lixula do not entirely overlap their settlement peaks in the Canary Islands, as suggested by García-Sanz et al. (2014), and that smallscale variations in settlement timing of these species may occur. The lack of $A$. lixula settlers in Tossa de Mar during the sampling period proves that the settlement timings of the two species studied are far from being synchronized in the Mediterranean Sea, unlike in the Canary Islands. A probable explanation for this asynchrony is the reduced survival of $A$. lixula larvae in the cold water temperatures prevailing in the Mediterranean during the spring months (Wangensteen et al. 2013a), which would prompt the adult populations of this sea urchin to spawn during the summer season (Wangensteen et al. 2013b). However, further sampling experiments are needed in order to investigate the settlement behaviour of $A$. lixula in the northwestern Mediterranean.

Though little used in ecology, the coefficient of variation (Zar 1984) has been extensively used as a measure of reproducibility for many other analytical approaches (e.g. Horwitz 1982, Pinnegar and Polunin 1999, Herbst and Silldorff 2006). Our results show that the biofilter collectors consistently had the lowest values for the coefficient of variation, thus suggesting their higher reproducibility. However, because of the small number of experimental replicates for each condition $(n=3)$ used for calculating these coefficients, these results should be taken with caution.

Our results have implications for the design of an appropriate methodology for future studies aimed at evaluating settlement rates of echinoids. We suggest using biofilter ball collectors as the most suitable artificial collecting device for this sampling purpose. This result should be taken into consideration by authors who are using less efficient artificial collectors in which settlement rates could be underestimated and vary greatly among replicates. The choice of sampling method and periodicity are key steps towards obtaining accurate measurements of settlement processes of marine invertebrates for accurately understanding their species dynamics and life cycles. Furthermore, the use of standardized sampling techniques is essential in order to compare numerical values obtained from different studies and establish patterns of species worldwide, which are currently missing in this field of research.

We want to emphasize that in our study we aimed to assess the absolute number of settlers collected by the artificial collectors, in order to determine the most reliable device for quantitative studies of settlement rates rather than the collector that gathered the highest num- 
ber of individuals per surface area. Although brush collectors have been commonly used for this purpose due to their capability of gathering a high number of settlers per surface area, biofilter balls proved to collect higher absolute numbers of individuals in all the proposed treatments, and showed the highest reproducibility of the three artificial collectors tested. Accumulating less variation among replicates allows researchers to use fewer replicates in the experimental design and increases the reliability of the results. Thus, though they collect fewer individuals per surface area, the biofilter ball collectors are the most suitable and efficient device for carrying out quantitative experiments and spatial comparisons and for assessing changes over time.

\section{ACKNOWLEDGEMENTS}

We thank all the staff belonging to the BLUEROCK CGL2013-430908 project (Universidad de la Laguna) for providing the equipment, facilities and collaboration that made it possible to carry out this study. We also thank David Martínez, a member of Deep Ocean Diver 2.0 (Tenerife), and Ramón Roqueta and the staff of Andrea's Diving (Tossa de Mar) for their valuable assistance in the field. This work was funded by the projects CHALLENGEN CTM2013-48163 of the Spanish Government and COCONET 287844 of the European Community's Seventh Framework Programme (FP7/2007-2013).

\section{REFERENCES}

Anderson M.J. 2004. PERMANOVA 2-factor: a FORTRAN computer program for permutational multivariate analysis of variance using permutation tests. Department of Statistics, Univ. Auckland, Auckland.

Anderson M.J. 2005. Permutational multivariate analysis of variance. Department of Statistics, Univ. Auckland, Auckland.

Bak R.P.M. 1985. Recruitment patterns and mass mortalities in the sea urchin Diadema antillarum. Proc. 5th Int. Coral Reef Congress. 5: 267-272.

Balch T., Scheibling R.E. 2000. Temporal and spatial variability in settlement and recruitment of echinoderms in kelp beds and barrens in Nova Scotia. Mar. Ecol. Prog. Ser. 205: 139-154. http://dx.doi.org/10.3354/meps205139

Balch T., Scheibling R.E. 2001. Larval supply, settlement and recruitment in echinoderms. Echinoderm Studies 6: 1-83.

Balch T., Scheibling R.E., Harris L.G., et al. 1998. Variation in settlement of Strongylocentrotus droebachiensis in the northwest Atlantic: effects of spatial scale and sampling method. In: Mooi M., Telford M. (eds), Echinoderms. San Francisco. AA Balkema, Rotterdam, pp. 555-560.

Bonaviri C., Fernández T.V., Fanelli G., et al. 2011. Leading role of the sea urchin Arbacia lixula in maintaining the barren state in southwestern Mediterranean. Mar. Biol. 158(11): 2505-2513. http://dx.doi.org/10.1007/s00227-011-1751-2

Bonaviri C., Gianguzza P., Pipitone C., et al. 2012. Micropredation on sea urchins as a potential stabilizing process for rocky reefs. J. Sea Res. 73: 18-23. http://dx.doi.org/10.1016/j.seares.2012.06.003

Bulleri F., Benedetti-Cecchi L., Cinelli F. 1999. Grazing by the sea urchins Arbacia lixula L. and Paracentrotus lividus Lam. in the Northwest Mediterranean. J. Exp. Mar. Biol. Ecol. 241: 81-95. http://dx.doi.org/10.1016/S0022-0981(99)00073-8

Byrne M. 1990. Annual reproductive cycles of the commercial sea urchin Paracentrotus lividus from an exposed intertidal and a sheltered subtidal habitat on the west coast of Ireland. Mar. Biol. 104: 275-289. http://dx.doi.org/10.1007/BF01313269

Cameron R.A., Schroeter S.C. 1980. Sea urchin recruitment: effect of substrate selection on juvenile distribution. Mar. Ecol. Prog.
Ser. 2: 243-247

http //dx.doi.org/10.3354/meps002243

Clarke K.R., Gorley R.N. 2006. PRIMER v6: User manual/tutorial. PRIMER-E Ltd., Plymouth.

Clemente S. Hernández J.C., Brito A. 2009. Evidence of the topdown role of predators in structuring sublittoral rocky-reef communities in a Marine Protected Area and nearby areas of the Canary Islands. ICES J. Mar. Sci. 66: 64-71.

http://dx.doi.org/10.1093/icesjms/fsn176

Clemente S., Hernández J.C., Montaño-Moctezuma G., et al. 2013. Predators of juvenile sea urchins and the effect of habitat refuges. Mar. Biol. 160: 579-590. http://dx.doi.org/10.1007/s00227-012-2114-3

Ebert T.A., Schroeter S.C., Dixon J.D., et al. 1994. Settlement patterns of red and purple sea urchins (Strongylocentrotus franciscanus and $S$. purpuratus) in California, USA. Mar. Ecol. Prog. Ser. 111: 41-52 http://dx.doi.org/10.3354/meps 111041

Fenaux L. 1968. Maturation des gonades et cycle saisonnier des larves chez A. lixula, $P$. lividus et $P$. microtuberculatus (echinides) à Villefranche-Sur-Mer. Vie Milieu 19: 1-52.

García-Sanz S., Tuya F., Navarro P.G., et al. 2012. Post larval, short-term, colonization patterns: the effect of substratum complexity across subtidal, adjacent, habitats. Est. Coast. Shelf. Sci. 112: $183-191$ http://dx.doi.org/10.1016/j.ecss.2012.07.014

García-Sanz S., Navarro P.G., Tuya F. 2014. Contrasting recruitment seasonality of sea urchin species in Gran Canaria, Canary Islands (eastern Atlantic). Medit. Mar. Sci. 15: 475-481.

Girard D., Hernández J.C., Toledo K., et al. 2006. Aproximación a la biología reproductiva del equinoideo Paracentrotus lividus (Lamarck, 1816) en el litoral de Tenerife. Proceedings of the XIV SIEBM.

Guidetti P., Dulčić J. 2007. Relationships among predatory fish, sea urchins and barrens in Mediterranean rocky reefs across a latitudinal gradient. Mar. Environ. Res. 63(2): 168-184. http://dx.doi.org/10.1016/j.marenvres.2006.08.002

Guidetti P., Fraschetti S., Terlizzi A., et al. 2003. Distribution patterns of sea urchins and barrens in shallow Mediterranean rocky reefs impacted by the illegal fishery of the rock-boring mollusc Lithophaga lithophaga. Mar. Biol. 143: 1135-1142. http://dx.doi.org/10.1007/s00227-003-1163-z

Harrold C., Pearse J.S. 1987. The ecological role of echinoderms in kelp forests. Echinoderm Studies 2: 137-233.

Harrold C., Lisin S., Light K.H., et al. 1991. Isolating settlement from recruitment of sea urchins. J. Exp. Mar. Biol. Ecol. 147: $81-94$. http://dx.doi.org/10.1016/0022-0981(91)90038-X

Herbst D.B., Silldorff E.L. 2006. Comparison of the performance of different bioassessment methods: similar evaluations of biotic integrity from separate programs and procedures. J. N. Am. Benthol. Soc., 25(2): 513-530. http://dx.doi.org/10.1899/0887-3593(2006)25[513:COTPOD]2 $0 . \mathrm{CO} ; 2$

Hereu B., Zabala M., Linares C., et al. 2004. Temporal and spatial variability in settlement of the sea urchin Paracentrotus lividus in the NW Mediterranean. Mar. Biol. 144: 1011-1018. http://dx.doi.org/10.1007/s00227-003-1266-6

Hereu B., Linares C., Sala E., et al. 2012. Multiple processes regulate long-term population dynamics of sea urchins on Mediterranean rocky reefs. PloS ONE 7: e36901. http://dx.doi.org/10.1371/journal.pone.0036901

Hernández J.C., Toledo K., Girard D., et al. 2005. Descripción de la post-larva y primeras fases juveniles de tres equinoideos presentes en las islas Canarias: Diadema antillarum (Philippi, 1845), Paracentrotus lividus (Lamarck, 1816) y Arbaciella elegans (Mortensen, 1910). Vieraea 33: 385-397.

Hernández J.C., Brito A., Cubero E., et al. 2006. Temporal patterns of larval settlement of Diadema antillarum (Echinodermata: Echinoidea) in the Canary Islands using an experimental larval collector. Bull. Mar. Sci. 78: 271-279.

Hernández J.C., Clemente S., Sangil C., et al. 2008. The key role of the sea urchin Diadema aff. antillarum in controlling macroalgae assemblages throughout the Canary Islands (eastern subtropical Atlantic): an spatio-temporal approach. Mar. Env. Res. 66: 259-270. http://dx.doi.org/10.1016/j.marenvres.2008.03.002

Hernández J.C., Clemente S., Girard D., et al. 2010. Effect of temperature on settlement and postsettlement survival in a barrensforming sea urchin. Mar. Ecol. Prog. Ser. 413: 69-80. 
http://dx.doi.org/10.3354/meps08684

Hernández J.C., Clemente S., Tuya F., et al. 2013. Echinoderms of the Canary Islands, Spain. In: Alvarado J.J., Solis-Marin F.A., Echinoderm Research and Diversity in Latin America. Springer, Berlin-Heidelberg, pp. 471-510.

http://dx.doi.org/10.1007/978-3-642-20051-9_15

Horwitz W. 1982. Evaluation of analytical methods used for regulation of foods and drugs. Anal. Chem. 54(1), 67A-76A. http://dx.doi.org/10.1021/ac00238a765

Hunte W., Younglao D. 1988. Recruitment and population recovery of Diadema antillarum (Echinodermata; Echinoidea) in Barbados. Mar. Ecol. Prog. Ser. 45: 109-119. http://dx.doi.org/10.3354/meps045109

Irusta J.M.G., Jordana J.C.C., Ansorena F.J. 2008. El erizo de mar común (Paracentrotus lividus) en Cantabria: Estudio para una explotación sostenible. Locustella: Anuario de la Naturaleza de Cantabria 5: 58-67.

Jennings L.B., Hunt H.L. 2010. Settlement, recruitment and potential predators and competitors of juvenile echinoderms in the rocky subtidal zone. Mar. Biol. 157(2): 307-316. http://dx.doi.org/10.1007/s00227-009-1318-7

Keesing J.K., Cartwright C.M., Hall K.C. 1993. Measuring settlement intensity of echinoderms on coral reefs. Mar. Biol. 117: 399-407.

Kempf M. 1962. Recherches d'écologie comparée sur Paracentrotus lividus (Lmk.) et Arbacia lixula (L.). Rec Trav St Mar Endoume 25: 47-115.

Lamare M.D., Barker M.F. 2001. Settlement and recruitment of the New Zealand sea urchin Evechinus chloroticus. Mar. Ecol. Prog. Ser. 218: 153-166. http://dx.doi.org/10.3354/meps218153

Lambert D.M., Harris L.G. 2000. Larval settlement of the green sea urchin Strongylocentrotus droebachiensis in the southern Gulf of Maine. Invertebr. Biol. 119: 403-409. http://dx.doi.org/10.1111/j.1744-7410.2000.tb00110.x

Lawrence J.M. 1975. On the relationships between marine plants and sea urchins. Oceanogr. Mar. Biol. Annu. Rev. 13: 213-286.

Loosanoff V.L. 1964. Variations in time and intensity of setting of the starfish, Asterias forbesi, in Long Island Sound during a twenty-five-year period. Biol. Bull. 126: 423-439. http://dx.doi.org/10.2307/1539311

López S., Turon X., Montero E., et al. 1998. Larval abundance, recruitment and early mortality in Paracentrotus lividus (Echinoidea). Interannual variability and plankton-benthos coupling. Mar. Ecol. Prog. Ser. 72: 239-251. http://dx.doi.org/10.3354/meps 172239

Lozano J., Galera J., López S., et al. 1995. Biological cycles and recruitment of Paracentrotus lividus (Echinodermata: Echinoidea) in two contrasting habitats. Mar. Ecol. Prog. Ser. 122: 179-191. http://dx.doi.org/10.3354/meps122179

Micheli F., Benedetti-Cecchi L., Gambaccini S., et al. 2005. Cascading human impacts, marine protected areas, and the structure of Mediterranean reef assemblages. Ecol. Monogr. 75(1): 81-102. http://dx.doi.org/10.1890/03-4058

Miller B.A., Emlet R.B. 1997. Influence of nearshore hydrodynamics on larval abundance and settlement of sea urchins Strongylocentrotus franciscanus and $S$. purpuratus in the Oregon upwelling zone. Oceanogr. Lit. Rev. 44: 980-981. http://dx.doi.org/10.3354/meps148083

Ólafsson E.B., Peterson C.H., Ambrose W.G.Jr. 1994. Does recruitment limitation structure populations and communities of macro-invertebrates in marine soft sediments: the relative significance of pre-and post-settlement processes. Oceanogr. Mar. Biol. Annu. Rev. 32: 65-109.

Palacín C., Giribet G., Carner S., et al. 1998. Low densities of sea urchins influence the structure of algal assemblages in the western Mediterranean. J. Sea Res. 39: 281-290. http://dx.doi.org/10.1016/S1385-1101(97)00061-0

Pawlik J.R. 1992. Chemical ecology of the settlement of benthic marine invertebrates. Oceanogr. Mar. Biol. Annu. Rev. 30: 273-335.

Pinnegar J.K., Polunin N.V.C. 1999. Differential fractionation of $\delta 13 \mathrm{C}$ and $\delta 15 \mathrm{~N}$ among fish tissues: implications for the study of trophic interactions. Funct. Ecol. 13(2): 225-231. http://dx.doi.org/10.1046/j.1365-2435.1999.00301.x

Privitera D., Chiantore M., Mangialajo L., et al. 2008. Inter-and intra-specific competition between Paracentrotus lividus and Arbacia lixula in resource-limited barren areas. J. Sea Res. 60: 184-192. http://dx.doi.org/10.1016/j.seares.2008.07.001

Privitera D., Noli M., Falugi C., et al. 2011. Benthic assemblages and temperature effects on Paracentrotus lividus and Arbacia lixula larvae and settlement. J. Exp. Mar. Biol. Ecol. 407: 6-11. http://dx.doi.org/10.1016/j.jembe.2011.06.030

Régis M.B. 1978. Croissance de deux échinoïdes du golfe de Marseille (Paracentrotus lividus (Lmk) et Arbacia lixula L.). Aspects écologiques de la microstructure du squelette et de l'évolution des indices physiologiques. Ph.D. thesis. Univ. AixMarseille III., 221 pp.

Rowley R.J. 1989. Settlement and recruitment of sea urchins (Strongylocentrotus spp.) in a sea-urchin barren ground and a kelp bed: are populations regulated by settlement or post-settlement processes? Mar. Biol. 100: 485-494. http://dx.doi.org/10.1007/BF00394825

Sala E., Zabala M. 1996. Fish predation and the structure of the sea urchin Paracentrotus lividus populations in the NW Mediterranean. Mar. Ecol. Prog. Ser. 140: 71-81. http://dx.doi.org/10.3354/meps140071

Sala E., Ribes M., Hereu B., et al. 1998. Temporal variability in abundance of the sea urchins Paracentrotus lividus and Arbacia lixula in the northwestern Mediterranean: comparison between a marine reserve and an unprotected area. Mar. Ecol. Prog. Ser. 168: $135-145$. http://dx.doi.org/10.3354/meps168135

Sánchez-España A.I., Martínez-Pita I., García F.J. 2004. Gonadal growth and reproduction in the commercial sea urchin Paracentrotus lividus (Lamarck, 1816) (Echinodermata: Echinoidea) from southern Spain. Hydrobiologia 519: 61-72. http://dx.doi.org/10.1023/B:HYDR.0000026485.40173.02

Sangil C., Sansón M., Clemente S., et al. 2014. Contrasting the species abundance, species density and diversity of seaweed assemblages in alternative states: Urchin density as a driver of biotic homogenization. J. Sea Res. 85: 92-103. http://dx.doi.org/10.1016/j.seares.2013.10.009

Tegner M.J. 1989. The feasibility of enhancing red sea urchin, Strongylocentrotus franciscanus, stocks in California: an analysis of the options. Mar. Fish. Rev. 51: 1-22.

Tomas F., Romero J., Turon X. 2004. Settlement and recruitment of the sea urchin Paracentrotus lividus in two contrasting habitats in the Mediterranean. Mar. Ecol. Prog. Ser. 282: 173-184. http://dx.doi.org/10.3354/meps282173

Tuya F., Cisneros-Aguirre J., Ortega-Borges L., et al. 2007. Bathymetric segregation of sea urchins on reefs of the Canarian Archipelago: role of flow-induced forces. Estuar. Coast. Shelf Sci. 73: 481-488. http://dx.doi.org/10.1016/j.ecss.2007.02.007

Uthicke S., Schaffelke B., Byrne M. 2009. A boom-bust phylum? Ecological and evolutionary consequences of density variations in echinoderms. Ecol. Monogr. 79: 3-24. http://dx.doi.org/10.1890/07-2136.1

Verlaque M. 1987. Relations entre Paracentrotus lividus (Lamarck) et le phytobenthos de Méditerranée occidentale. In: Boudouresque C.F. (ed.), Colloque International sur Paracentrotus lividus et les oursins comestibles. GIS Posidonie publ. Marseille, pp. 5-36.

Victor B.C. 1986. Larval settlement and juvenile mortality in a recruitment-limited coral reef fish population. Ecol. Monogr. 56: $145-160$. http://dx.doi.org/10.2307/1942506

Wangensteen O.S., Turon X., García-Cisneros A., et al. 2011. A wolf in sheep's clothing: carnivory in dominant sea urchins in the Mediterranean. Mar. Ecol. Prog. Ser. 441: 117-128. http://dx.doi.org/10.3354/meps09359

Wangensteen O.S., Turon X., Pérez-Portela R., et al. 2012. Natural or naturalized? Phylogeography suggests that the abundant sea urchin Arbacia lixula is a recent colonizer of the Mediterranean. PLoS ONE, 7: e45067. http://dx.doi.org/10.1371/journal.pone.0045067

Wangensteen O.S., Dupont S., Casties I., et al. 2013a. Some like it hot: Temperature and $\mathrm{pH}$ modulate larval development and settlement of the sea urchin Arbacia lixula. J. Exp. Mar. Biol. Ecol. 449: 304-311. http://dx.doi.org/10.1016/j.jembe.2013.10.007

Wangensteen O.S., Turon X., Casso M., et al. 2013b. The reproductive cycle of the sea urchin Arbacia lixula in northwest Mediterranean: potential influence of temperature and photoperiod. Mar. Biol. 160: 3157-3168. http://dx.doi.org/10.1007/s00227-013-2303-8

Zar J.H. 1984. Biostatistical analysis, 2nd edn. Prentice-Hall, Englewood Cliffs. 


\section{SUPPLEMENTARY MATERIAL}

The following material is available through the online version of this article and at the following link:

http://www.icm.csic.es/scimar/supplm/sm04252esm.pdf

Table S1. - Results of the three-way permutational analysis of variance (PERMANOVA) performed to identify significant differences in the number of $P$. lividus settlers $/ \mathrm{m}^{2}$ between the factors 'Collector', 'Time' and 'Locality' (Abades and Tossa de Mar). Significant results are shown in bold $(* \mathrm{p}<0.05 ; * * \mathrm{p}<0.01)$.

Table S2. - Pairwise comparisons for the significant interaction of the factors 'Collector $\times$ Locality' obtained in the permutational analysis of variance (PERMANOVA) assessing differences in number of $P$. lividus settlers per unit area. Differences in settlers $/ \mathrm{m}^{2}$ densities at Abades (during February 2012) and at Tossa de Mar (during June 2012) among the three kinds of artificial collector tested are given. Significant results are shown in bold $(* \mathrm{p}<0.05 ; * * \mathrm{p}<0.01)$
Table S3. - Results of the two-way permutational analysis of variance (PERMANOVA) performed to identify significant differences in the number of $A$. lixula settlers $/ \mathrm{m}^{2}$ between the factors 'Collector' and 'Time' at the Canary Islands site (Abades). Significant results are shown in bold $(* \mathrm{p}<0.05 ; * * \mathrm{p}<0.01)$.

Table S4. - Pairwise comparisons for the significant factors 'Collector' obtained in the permutational analysis of variance (PERMANOVA) assessing differences in number of A. lixula settlers $/ \mathrm{m}^{2}$ collected at Abades in February 2012. Differences in settlers densities among the three kinds of artificial collectors tested are given. Significant results are shown in bold $(* \mathrm{p}<0.05$; $* * \mathrm{p}<0.01)$

Fig. S1. - Number of Paracentrotus lividus settlers $/ \mathrm{m}^{2}$ found in the artificial collectors deployed at Abades and Tossa de Mar in February and June 2012, respectively. Error bars show standard deviations.

Fig. S2. - Number of Arbacia lixula settlers $/ \mathrm{m}^{2}$ found in the artificial collectors deployed at Abades in February 2012. Error bars show standard deviation. 
Scientia Marina 80(2)

June 2016, S1-S3, Barcelona (Spain)

ISSN-L: 0214-8358

\section{Efficiency of artificial collectors for quantitative assessment of sea urchin settlement rates}

Marc Balsalobre, Owen S. Wangensteen, Creu Palacín, Sabrina Clemente, José Carlos Hernández

Supplementary material 
S2 - M. Balsalobre et al.

Table S1. - Results of the three-way permutational analysis of variance (PERMANOVA) performed to identify significant differences in the number of $P$. lividus settlers $/ \mathrm{m}^{2}$ between the factors 'Collector', 'Time' and 'Locality' (Abades and Tossa de Mar). Significant results are

\begin{tabular}{lccccc}
\multicolumn{5}{c}{ shown in bold $(* \mathrm{p}<0.05 ; * * \mathrm{p}<0.01)}$. \\
\hline Source & df & SS & MS & Pseudo-F & P(perm) \\
\hline Collector & 2 & 9277.4 & 4638.7 & 63.896 & $\mathbf{0 . 0 0 0 1} * *$ \\
Time & 1 & 31.392 & 31.392 & 0.43241 & 0.6165 \\
Locality & 1 & 1626.9 & 1626.9 & 22.409 & $\mathbf{0 . 0 0 0 1} * *$ \\
Collector $\times$ Time & 2 & 25.86 & 12.93 & 0.1781 & 0.9416 \\
Collector $\times$ Locality & 2 & 953.95 & 476.98 & 6.5701 & $\mathbf{0 . 0 0 0 9} * *$ \\
Time $\times$ Locality & 1 & 16.174 & 16.174 & 0.22278 & 0.7852 \\
Collector $\times$ Time $\times$ Locality & 2 & 52.088 & 26.044 & 0.35875 & 0.8094 \\
Residual & 24 & 1742.4 & 72.598 & & \\
Total & 35 & 13726 & & & \\
\hline
\end{tabular}

Table S2. - Pairwise comparisons for the significant interaction of the factors 'Collector $\times$ Locality' obtained in the permutational analysis of variance (PERMANOVA) assessing differences in number of $P$. lividus settlers per unit area. Differences in settlers $/ \mathrm{m}^{2}$ densities at Abades (during February 2012) and at Tossa de Mar (during June 2012) among the three kinds of artificial collector tested are given. Significant results are shown in bold $(* \mathrm{p}<0.05 ; * * \mathrm{p}<0.01)$.

\begin{tabular}{llcc}
\hline Locality & Collectors & $\mathrm{T}$ & $\mathrm{P}($ perm $)$ \\
\hline \hline Abades & Biofilter, Mat & 6.0721 & $\mathbf{0 . 0 0 2 6} * *$ \\
& Biofilter, Brush & 5.4438 & $\mathbf{0 . 0 0 3 6} * *$ \\
& Mat, Brush & 9.8611 & $\mathbf{0 . 0 0 2 3} * *$ \\
Tossa de Mar & Biofilter, Mat & 2.9239 & $\mathbf{0 . 0 2 5 2} * *$ \\
& Biofilter, Brush & 3.6942 & $\mathbf{0 . 0 0 6 7} * *$ \\
& Mat, Brush & 5.0637 & $\mathbf{0 . 0 0 2 4} * *$ \\
\hline
\end{tabular}

Table S3. - Results of the two-way permutational analysis of variance (PERMANOVA) performed to identify significant differences in the number of A. lixula settlers $/ \mathrm{m}^{2}$ between the factors 'Collector' and 'Time' at the Canary Islands site (Abades). Significant results are shown in bold $(* \mathrm{p}<0.05 ; * * \mathrm{p}<0.01)$.

\begin{tabular}{lccccc}
\hline Source & df & SS & MS & Pseudo-F & P(perm) \\
\hline Collector & 2 & 4017.6 & 2008.8 & 7.4269 & $\mathbf{0 . 0 0 1 8} * *$ \\
Time & 1 & 7258.1 & 7258.1 & 26835 & $\mathbf{0 . 0 0 0 6} * *$ \\
Collector $\times$ Time & 2 & 1103.1 & 551.53 & 2.0391 & 0.1253 \\
Residual & 12 & 3245.7 & 270.48 & & \\
Total & 17 & 15625 & & \\
\hline
\end{tabular}

Table S4. - Pairwise comparisons for the significant factors 'Collector' obtained in the permutational analysis of variance (PERMANOVA) assessing differences in number of A. lixula settlers $/ \mathrm{m}^{2}$ collected at Abades in February 2012. Differences in settlers densities among the three kinds of artificial collectors tested are given. Significant results are shown in bold $(* \mathrm{p}<0.05 ; * * \mathrm{p}<0.01)$.

\begin{tabular}{lcc}
\hline Collectors & $\mathrm{T}$ & $\mathrm{P}($ perm $)$ \\
\hline Biofilter, Brush & 1.2207 & 0.272 \\
Biofilter, Mat & 7.7712 & $\mathbf{0 . 0 0 2 8} * *$ \\
Mat, Brush & 2.7518 & $\mathbf{0 . 0 1 1 9} *$ \\
\hline
\end{tabular}




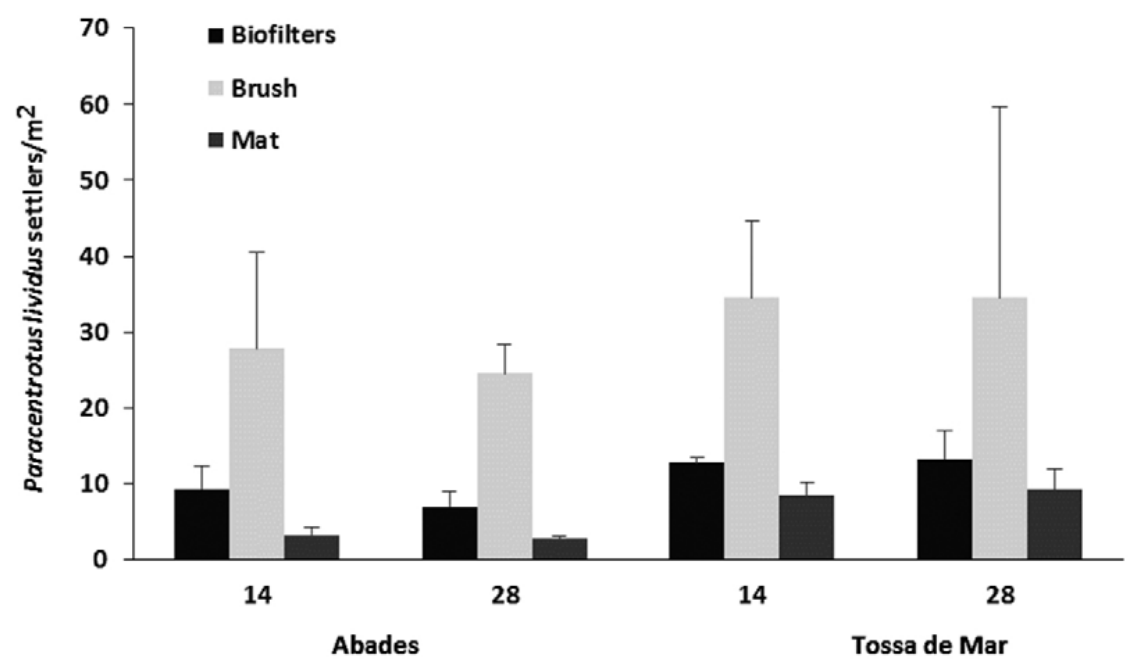

Fig. S1. - Number of Paracentrotus lividus settlers $/ \mathrm{m}^{2}$ found in the artificial collectors deployed at Abades and Tossa de Mar in February and June 2012, respectively. Error bars show standard deviations.

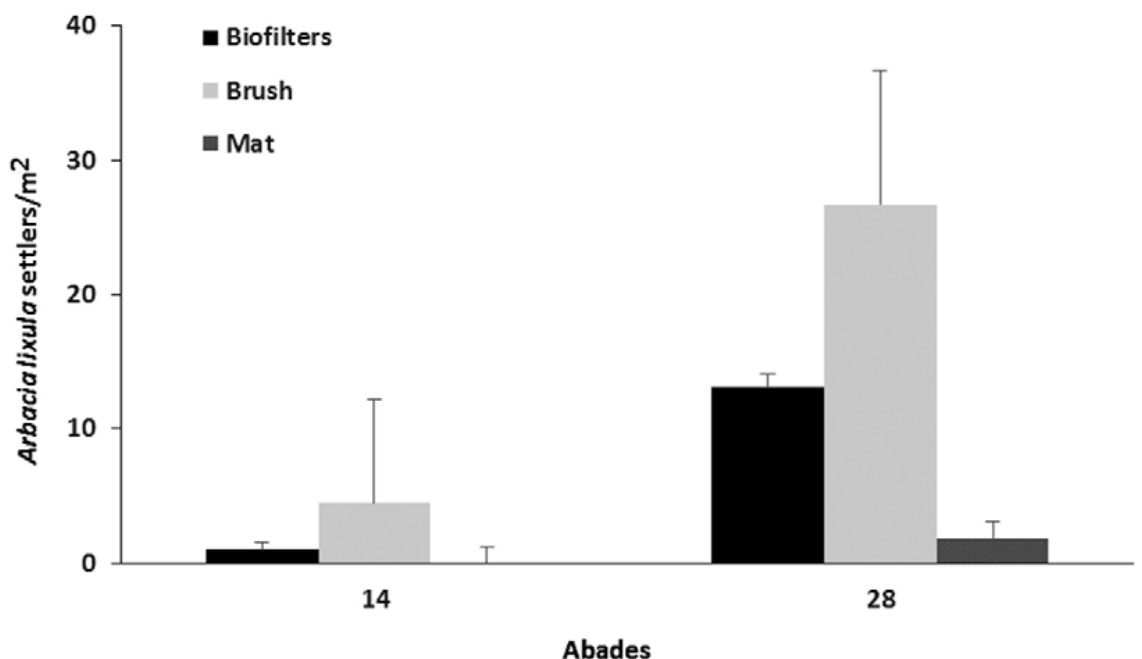

Fig. S2. - Number of Arbacia lixula settlers $/ \mathrm{m}^{2}$ found in the artificial collectors deployed at Abades in February 2012. Error bars show standard deviation 